Scientific note - Znanstvena nota

UDK: 637.146 .34

\title{
Effect of dandelion extract, sucrose and starter culture on the viscosity, water-holding capacity and $\mathrm{pH}$ of plain yogurt
}

\author{
doi: $10.15567 /$ mljekarstvo.2017.0408 \\ Shuwei Yao ${ }^{1}$, Siyu Xie ${ }^{2}$, Lianzhou Jiang ${ }^{1}$, Liang $\mathrm{Li}^{1 *}$ \\ ${ }^{1}$ Northeast Agricultural University, College of Food Science, \\ 59 Mucai Street, Gongbin Road, Harbin, Heilongjiang 150030, China \\ ${ }^{2}$ China Agricultural University, \\ College of Food Science and Nutritional Engineering, Beijing, 100083, China \\ Received - Prispjelo: 26.04.2017. \\ Accepted - Prihvaćeno: 27.09.2017.
}

\begin{abstract}
Dandelion extract is a traditional Chinese medicine and contains significant nutritional value. The aim of this study was to research the optimum fermentation conditions for dandelion addition to plain yogurt using a single factor experiments and orthogonal experiment. The results of the present study demonstrated that the addition of dandelion extract affected the viscosity, water-holding capacity and $\mathrm{pH}$ of yogurt. Optimized conditions for dandelion addition to plain yogurt based on viscosity, incubation time, $\mathrm{pH}$ and sensory score were $10 \%$ sucrose, $0.3 \%$ of the starter cultures, incubation time of 6.5 hours and $3 \%$ dandelion extract. A new kind of dandelion yogurt with high viscosity, good water-holding capacity and good taste was prepared in this study.
\end{abstract}

Key words: dandelion, yogurt, viscosity, water-holding capacity, $\mathrm{pH}$

\section{Introduction}

Yogurt is a fermented milk product that has been used for thousands of years. It is a dairy product manufactured from milk fermented by Streptococcus thermophilus and Lactobacillus delbrueckii subsp. bulgaricus (Glibowski and Rybak, 2016). It is considered by nutritionists to have a high nutritional value and positive bioactive effects. To satisfy consumer demands, a number of additional ingredients may be added to yogurt, including natural or artificial colors, sucrose or artificial sweeteners, texturizing agents (Sørensen et al., 2016), prebiotic ingredients and probiotic bacteria (Oliveira et al., 2015). In recent years, some vegetable (Kiros et al., 2016) and fruit preparations (Oliveira et al., 2015) along with plants extracts (Balthazar et al., 2015; Bansal et al., 2016; Hussein et al., 2011; Parsa et al., 2015; Hashemi et al., 2016) have been added into yogurt.
Taraxacum officinale, known as the dandelion, is a member of the Asteraceae/Compositae family. It is a perennial herb that is inherent to the Northern hemisphere (You et al., 2010). The dandelion plant has been used as a phytomedicine for its choleretic, diuretic, anti-rheumatic, anti-diabetic and anti-inflammatory properties (Wang, 2014). Dandelion extract can alleviate high-fat diet-induced nonalcoholic fatty liver (Davaatseren et al., 2013), can supply the antitumor effects of cancer cells with the presence of both luteolin and luteolin 7-glucoside (Hu and Kitts, 2003; Menke et al., 2015) and have antibacterial and antioxidant activities (Ghaima et al., 2013). Dandelion extract is used by a traditional Chinese medicine. Despite the significant nutritional value assured by the present flavonoids, cinnamic acids and coumarins (Williams et al.,1996), it is rarely used as a food. A mixture of yogurt and dandelion extract is a rich, nutritional healthy beverage. 
Dandelion yogurt is a suitable drink for people of all ages. This drink provides more choices for consumers and also supports the use of Chinese herbal medicines in the dairy industry.

The aim of this paper was to study the effects of dandelion extract on the viscosity, water-holding capacity and $\mathrm{pH}$ of yogurt and to improve yogurt parameters made from milk by mixing dandelion extract.

\section{Materials and Methods}

\section{Materials}

Dried dandelion was purchased from a pharmacy in Harbin (China). Fresh milk (3\% protein) and sucrose were purchased from a market in Harbin (China). Yogurt Starter cultures were purchased from Harbin Meihua Biotechnology (Harbin, China).

\section{Preparation of the dandelion extracts and yogurt}

The preparation of the dandelion extract was performed according to a method previously described with modifications (You et al., 2010). The dried dandelion was extracted 16 times with distilled water for $5 \mathrm{~min}$ at $100{ }^{\circ} \mathrm{C}$, and the extracted solution was then filtered.

Set yogurt was prepared using a previously published method with modifications (Miocinovic et al., 2016). The milk was heat-treated $\left(95{ }^{\circ} \mathrm{C}\right.$, $5 \mathrm{~min}$ ), cooled to $43^{\circ} \mathrm{C}$. After cooling, the dandelion extract and starter cultures were added into the milk. After incubation the samples were kept at $4{ }^{\circ} \mathrm{C}$ until further analysis.

\section{Experimental design}

The amount of sucrose $(8 \%, 10 \%, 12 \%)$, starter cultures $(0.1 \%, 0.2 \%)$, incubation time $(5.5 \mathrm{~h}, 6 \mathrm{~h}$, $6.5 \mathrm{~h})$ and dandelion extract (1\%, $2 \%, 3 \%)$ were studied by a single factor experiments. The level of

Table 1. Factors and levels of orthogonal experiment

\begin{tabular}{ccccc}
\hline $\begin{array}{c}\text { Sucrose/\% } \\
\text { (A) }\end{array}$ & $\begin{array}{c}\text { Starter } \\
\text { cultures/\% } \\
\text { (B) }\end{array}$ & $\begin{array}{c}\text { Incubation } \\
\text { time/h } \\
\text { (C) }\end{array}$ & $\begin{array}{c}\text { Dandelion } \\
\text { extract } / \% \\
\text { (D) }\end{array}$ \\
\hline 1 & 8 & 0.1 & 5.5 & 1 \\
\hline 2 & 10 & 0.2 & 6 & 2 \\
\hline 3 & 12 & 0.3 & 6.5 & 3 \\
\hline
\end{tabular}

sucrose, the starter cultures, incubation time and dandelion extract in orthogonal experiment were shown in Table 1.

\section{Viscosity of the yogurt}

The apparent viscosity of the samples was recorded at a shear rate of $6 \mathrm{rpm}$ using a NDJ-5S digital rotational viscometer (Shanghai, China), and the viscosity was expressed in $\mathrm{mPa}$.

\section{Water-holding capacity of the yogurt}

The water-holding capacity of the yogurt was determined by a procedure developed by Keogh and Li with modifications (Keogh and O'Kennedy, 1998; Li and Guo, 2006). $20 \mathrm{~g}$ of yogurt (Y) was centrifuged by a GL-20G-II refrigerated centrifuge (Shanghai Anting Scientific Instrument Factory, Shanghai, China) at $4000 \mathrm{~g}$ for $20 \mathrm{~min}$ at $4{ }^{\circ} \mathrm{C}$. The supernatant was poured off, and the precipitation (W) was weighed.

Water holding capacity was calculated according to the equation (1):

Water-holding capacity $(\%)=(\mathrm{W} / \mathrm{Y}) \times 100 \%$

where $W$ presents mass of the precipitation and $Y$ presents mass of analyzed yogurt.

\section{pH of the yogurt}

The $\mathrm{pH}$ of the yogurt was determined using a PHM220 pH meter (Radiometer analytical, France).

\section{Sensory evaluation}

The sensory evaluation of yogurt samples was performed by a method of adjustment (Staffolo et al., 2004; Hekmat and Reid, 2006). Yogurt samples were presented to 10 members. Sensory analysis approach was used to determine consumer acceptability. Color, flavor, taste and texture were analyzed. The hedonic scale varied from 25 (like very much) to 1 (dislike).

\section{Statistical analyses}

The experiment was repeated three times. The average, and the standard deviation was calculated. All of the analyses were carried out using the SPSS.17 software (SPSS, Inc., Chicago, IL, USA). 


\section{Results}

\section{Effects of sucrose on yogurt parameters}

As presented in Table 2, sucrose had a significant influence on yogurt parameters. The viscosity, water-holding capacity and $\mathrm{pH}$ of yogurt containing $8 \%$ sucrose were $317.33 \mathrm{mPas}, 33.72 \%$ and 5.43 , respectively. The viscosity increased along with the increase in sucrose concentration, but the waterholding capacity and $\mathrm{pH}$ decreased as the concentration of the sucrose increased. These $\mathrm{pH}$ results did not agree with the results reported by Slocum et al. (1988) for yogurt containing sucrose. They found that the addition of sucrose decreased the acid production by the microorganisms in yogurt. That phenomenon might be due to the high concentration of sucrose (15\%) used in their study (Slocum et al., 1988).

\section{Effects of the amount of the starter cultures on yogurt parameters}

The effects of the starter culture amount on viscosity, water-holding capacity and $\mathrm{pH}$ were reported in Table 3.

As shown in Table 3, the viscosity of yogurt with $0.2 \%$ of the starter cultures were higher than the corresponding values for yogurt containing $0.1 \%$ of the starter cultures. The $\mathrm{pH}$ of all of the yogurt samples decreased after fermentation.
The $\mathrm{pH}$ of the yogurt with $0.2 \%$ of the starter cultures was 4.56. A similar result was observed for yogurt samples prepared by the Lactobacillus plantarum WCFS1 culture, resulting in an average $\mathrm{pH}$ value of $4.5 \pm 0.1$ at the end of fermentation (Settachaimongkon et al., 2016). The addition of $0.2 \%$ of the starter cultures was efficient in lowering $\mathrm{pH}$ to a value below 4.6 at which caseins aggregate (Settachaimongkon et al., 2014). Therefore, the appropriate amount of the starter cultures was $0.2 \%$.

\section{Effects of the amount of dandelion extract on yogurt parameters}

The viscosity, $\mathrm{pH}$ and water holding capacity of yogurt with different amounts of dandelion extract were determined. The data was listed in Table 4.

As shown in Table 4, yogurt manufactured with addition of $2 \%$ dandelion extract had the highest viscosity and the lowest $\mathrm{pH}$. This may be because of the nutritional components that were extracted from dandelion. Every $100 \mathrm{~g}$ of dry dandelion contain $15.48 \mathrm{~g}$ of protein and $695 \mathrm{mg}$ of $\mathrm{Ca}$ (Escudero et al., 2003) along with higher levels of carbohydrates (77.35 g) and total sugars (6.53 g) (Dias et al., 2014). Research showed that the water-holding capacity was increased by adding polysaccharide stabilizers, which interact with the casein network (Everett and McLeod, 2005). Yogurt

Table 2. Effects of sucrose on the yogurt parameters

\begin{tabular}{ccccc}
\hline & Sucrose (\%) & Viscosity (mPas) & Water-holding capacity (\%) & $\mathrm{pH}$ \\
\hline 1 & 8 & $317.33 \pm 0.58$ & $33.72 \pm 1.73$ & $5.43 \pm 0.04$ \\
\hline 2 & 10 & $2310.00 \pm 34.64$ & $28.65 \pm 1.30$ & $5.06 \pm 0.10$ \\
\hline
\end{tabular}

Table 3. Effects of the amount of starter cultures on yogurt parameters

\begin{tabular}{ccccc}
\hline & Starter cultures (\%) & Viscosity (mPas) & Water-holding capacity (\%) & $\mathrm{pH}$ \\
\hline 1 & 0.1 & $2310 \pm 34.65$ & $28.65 \pm 1.30$ & $5.06 \pm 0.10$ \\
\hline 2 & 0.2 & $3063.33 \pm 98.15$ & $29.01 \pm 0.33$ & $4.56 \pm 0.09$ \\
\hline
\end{tabular}

Table 4. Effects of the amount of dandelion extract on yogurt parameters

\begin{tabular}{ccccc}
\hline & Dandelion (\%) & Viscosity (mPas) & Water-holding capacity (\%) & $\mathrm{pH}$ \\
\hline A & 1 & $2303.33 \pm 23.09$ & $28.29 \pm 2.45$ & $4.77 \pm 0.09$ \\
\hline B & 2 & $3543.33 \pm 236.71$ & $29.89 \pm 1.05$ & $4.52 \pm 0.06$ \\
\hline C & 3 & $1676.67 \pm 23.09$ & $27.76 \pm 0.36$ & $4.68 \pm 0.06$ \\
\hline
\end{tabular}


with ethanol-soluble polysaccharides had a higher viscosity than the control (Hussein et al., 2011). Water-holding capacity and $\mathrm{pH}$ of yogurt manufactured with $3 \%$ dandelion extract were very close to $1 \%$ dandelion extract, viscosity was even lower than $1 \%$ dandelion. These phenomena may be due to the fact that the addition of $3 \%$ dandelion extract probably brought more antibacterial substances and water into the system. Wang also reported that the water-soluble polysaccharides in dandelion have antibacterial activity (Wang, 2014). The increase of antibacterial substances inhibited the growth of starter cultures, and the increase of water may affected the viscosity and water-holding capacity of yogurt.

\section{Effects of time on the yogurt parameters}

The incubation time significantly influenced yogurt parameters. The yogurt samples fermented at $43{ }^{\circ} \mathrm{C}$ for $5.5 \mathrm{~h}$ lacked yogurt flavor but the yogurt samples fermented at $43{ }^{\circ} \mathrm{C}$ for $6.5 \mathrm{~h}$ formed a lot of separated whey.

Different raw materials added into yogurt might have changed incubation times of yogurt, as Bansal et al. (2016) found that incubation at $38^{\circ} \mathrm{C}$ for $12 \mathrm{~h}$ was optimal for peanut yogurt preparation.

\section{Orthogonal design experiment}

In this study, the experiments were based on an orthogonal design, L9 $\left(3^{4}\right)$, where the following four factors were analyzed: the sucrose concentration (A), starter culture concentration (B), incubation time (C) and dandelion extract concentration (D). Three levels were chosen for each factor in the experiment (Table 1). The results were shown in Table 5. The average responses for the individual factors at different levels were calculated and used to evaluate the efficiency and to optimize the experimental conditions (Wu et al., 2012).

The calculation process of the mean and range was referred to Tang, Wu and Liu 's method (Tang et al., 2016; Wu et al., 2011; Liu et al., 2016). The results were presented in Figs 1-3. Figs 1-3 were used to obtain the optimized yogurt preparation conditions.

As seen in Fig 1, the optimum condition with the highest viscosity value was A2B3C3D3, which corresponded to $10 \%$ sucrose, $0.3 \%$ of the starter cultures, a $6.5 \mathrm{~h}$ incubation time, and $3 \%$ dandelion extract. The ranges (R) of factors A - D were 850, $1471.3,988.9$ and 651 , respectively (Table 5). Thus, the order of influence on the viscosity was: starter cultures $>$ incubation time $>$ sucrose $>$ dandelion extract.

Table 5. The results of orthogonal test

\begin{tabular}{cccccccc}
\hline & \multicolumn{3}{c}{ Factors } & \multicolumn{3}{c}{ Results } \\
\cline { 2 - 8 } & $\begin{array}{c}\text { Sucrose/\% } \\
(\mathrm{A})\end{array}$ & $\begin{array}{c}\text { Starter } \\
\text { cultures/\% } \\
(\mathrm{B})\end{array}$ & $\begin{array}{c}\text { Incubation } \\
\text { time/h } \\
(\mathrm{C})\end{array}$ & $\begin{array}{c}\text { Dandelion } \\
\text { extract } / \% \\
(\mathrm{D})\end{array}$ & $\begin{array}{c}\text { Viscosity } \\
\text { (a) }\end{array}$ & $\begin{array}{c}\text { Water-holding } \\
\text { capacity } \\
\text { (b) }\end{array}$ & $\begin{array}{c}\mathrm{pH} \\
(\mathrm{c})\end{array}$ \\
\hline $\mathrm{l}$ & $8 \%$ & $0.1 \%$ & $5.5 \mathrm{~h}$ & $1 \%$ & 1540 & 32.29 & 4.76 \\
\hline 2 & $8 \%$ & $0.2 \%$ & $6.0 \mathrm{~h}$ & $2 \%$ & 3213 & 32.09 & 4.54 \\
\hline 3 & $8 \%$ & $0.3 \%$ & $6.5 \mathrm{~h}$ & $3 \%$ & 4460 & 32.69 & 4.36 \\
\hline 4 & $10 \%$ & $0.1 \%$ & $6.0 \mathrm{~h}$ & $3 \%$ & 3803 & 31.93 & 4.56 \\
\hline 5 & $10 \%$ & $0.2 \%$ & $6.5 \mathrm{~h}$ & $1 \%$ & 4290 & 32.54 & 4.44 \\
\hline 6 & $10 \%$ & $0.3 \%$ & $5.5 \mathrm{~h}$ & $2 \%$ & 3670 & 32.36 & 4.54 \\
\hline 7 & $12 \%$ & $0.1 \%$ & $6.5 \mathrm{~h}$ & $2 \%$ & 3180 & 33.27 & 4.51 \\
\hline 8 & $12 \%$ & $0.2 \%$ & $5.5 \mathrm{~h}$ & $3 \%$ & 3753 & 33.68 & 4.49 \\
\hline 9 & $12 \%$ & $0.3 \%$ & $6.0 \mathrm{~h}$ & $1 \%$ & 4807 & 32.76 & 4.40 \\
\hline $\mathrm{Ra}$ & 850 & 1471.3 & 988.9 & 651 & & & \\
\hline $\mathrm{Rb}$ & 0.960 & 0.273 & 0.573 & 0.237 & & & \\
\hline $\mathrm{Rc}$ & 0.086 & 0.177 & 0.160 & 0.063 & & & \\
\hline
\end{tabular}

Note: $\mathrm{Ra}, \mathrm{Rb}$ and $\mathrm{Rc}$ were defined as the $\mathrm{R}$ value related to viscosity, water-holding capacity and $\mathrm{pH}$ respectively 
The order of influence on the water holding capacity of yogurt was: sucrose $>$ incubation time $>$ starter cultures $>$ dandelion extract, based on their roles in the $\mathrm{R}$ values degree (Table 5). The optimum condition was $\mathrm{A} 3 \mathrm{~B} 2 \mathrm{C} 3 \mathrm{D} 3$, which corresponded to $12 \%$ sucrose, $0.2 \%$ of the starter cultures, a $6.5 \mathrm{~h}$ incubation time, and $3 \%$ dandelion extract.

As seen from the results in Table 5, the influence of $\mathrm{pH}$ on yogurt is in the order of: $\mathrm{B}>\mathrm{C}>\mathrm{A}$ $>\mathrm{D}$, according to the $\mathrm{R}$ values. The optimum combination for the lowest $\mathrm{pH}$ was: $12 \%$ sucrose (A3), $0.3 \%$ of the starter cultures (B3), a $6.5 \mathrm{~h}$ incubation time, (C3) and $3 \%$ dandelion extract (D3).

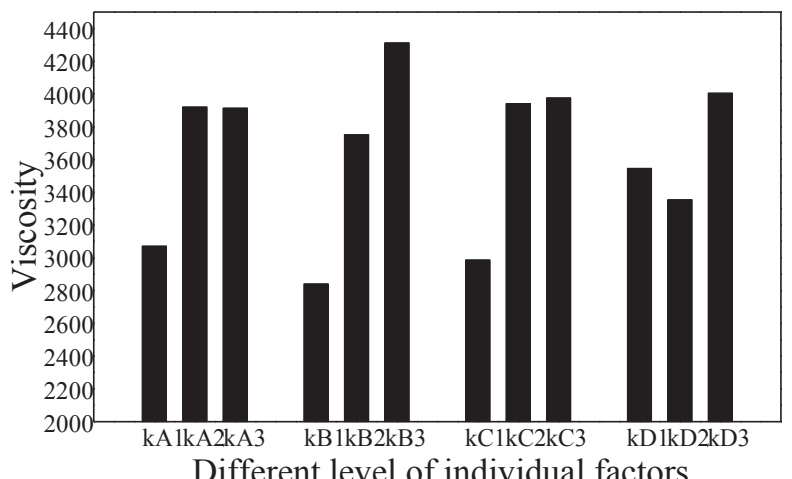

Figure 1. Effects of sucrose (A), starter cultures (B), incubation time $(\mathrm{C})$, and dandelion extract (D) on viscosity of yogurt (kji was defined as the mean value of the sum of the evaluation indexes of all levels (i, $i=1,2,3)$ in each factor $(j, j=A, B, C, D))$.

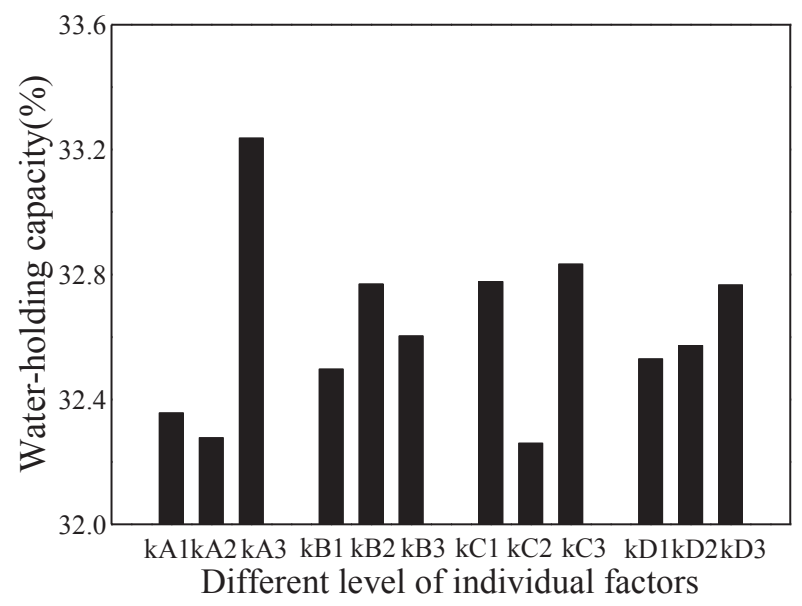

Figure 2. Effects of sucrose (A), starter cultures (B), incubation time $(\mathrm{C})$, and dandelion extract (D) on water-holding capacity of yogurt ( $\mathrm{kji}$ was defined as the mean value of the sum of the evaluation indexes of all levels $(i, i=1$, $2,3)$ in each factor $(j, j=A, B, C, D)$
A confirmation experiment was performed by analyzing A2B3C3D3, A3B2C3D3 and A3B3C3D3. The A2B3C3D3 combination for yogurt was found to have the best sensory scores (Table 6). The A2B3C3D3 had a light dandelion flavor, moderate acidity, good taste, while the other two products lack of dandelion flavor and good taste.

\section{Conclusions}

The aim of this study was to examine the effect of adding dandelion extract on the viscosity, waterholding capacity and $\mathrm{pH}$ of plain yogurt and thus to increase the functional properties of yogurt made from milk by mixing dandelion extracts for production of the new functional product. We determined that the optimum conditions for yogurt preparation were: $10 \%$ sucrose, $0.3 \%$ of the starter cultures, a $6.5 \mathrm{~h}$ incubation time and $3 \%$ dandelion extract. A new kind of dandelion yogurt with high viscosity, good water-holding capacity and good taste was prepared in this study.

Table 6. Sensory evaluation

\begin{tabular}{cc}
\hline Optimum condition & Sensory evaluation \\
\hline A2B3C3D3 & $87.3 \pm 2.67$ \\
\hline A3B2C3D3 & $79.4 \pm 3.31$ \\
\hline A3B3C3D3 & $77.8 \pm 3.52$ \\
\hline
\end{tabular}

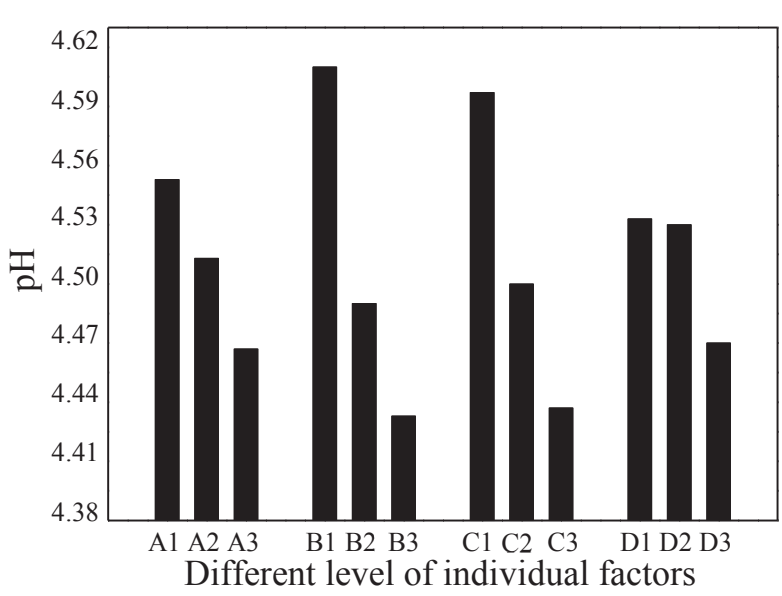

Figure 3. Effects of sucrose (A), starter cultures (B), incubation time $(C)$, and dandelion extract (D) on $\mathrm{pH}$ of yogurt (kji was defined as the mean value of the sum of the evaluation indexes of all levels ( $i, i=1,2,3)$ in each factor $(j, j=A, B, C, D)$ 


\section{Acknowledgements}

This study was supported by the National Natural Science Foundation of China (No.31401513), the Postdoctoral Research Fund of Heilongjiang Province (No.LBH-Z15021) and "Young Talents" Project of Northeast Agricultural University (No.14QC41).

\section{Utjecaj dodatka ekstrakta maslačka, saharoze i starter kulture na viskoznost, sposobnost zadržavanja vode i pH jogurta}

\section{Sažetak}

Ekstrakt maslačka je tradicionalni kineski lijek, a također ima i značajnu nutritivnu vrijednost. Cilj ovog istraživanja bio je ispitati optimalne uvjete fermentacije za dodavanje maslačka $\mathrm{u}$ jogurt korištenjem pojedinih faktorskih eksperimenata i ortogonalnog eksperimenta. Rezultati ove studije pokazali su da dodavanje ekstrakta maslačaka utječe na viskoznost, sposobnost zadržavanja vode i $\mathrm{pH}$ jogurta. Optimalni uvjeti za dodavanje maslačka u jogurt na temelju viskoznosti, vremena inkubacije, $\mathrm{pH}$ i senzorskog rezultata bili su $10 \%$ saharoze, 0,3\% starter kulture, vrijeme inkubacije od 6,5 sati i dodatak $3 \%$ ekstrakta maslačka. U ovoj studiji pripremljena je nova vrsta jogurta s dodatkom maslačka karakteriziranog visokom viskoznošću, dobrom sposobnošću zadržavanja vode i dobrim okusom.

Ključne riječi: maslačak, jogurt, viskoznost, kapacitet zadržavanja vode, $\mathrm{pH}$

\section{References}

1. Balthazar, C.F., Gaze, L.V., Azevedo da Silva, H.L., Pereira, C.S., Franco, R.M., Conte-Júnior, C.A., Freitas, M.Q.D., Silva, A.C.D.O. (2015): Sensory evaluation of ovine milk yoghurt with inulin addition. International Journal of Dairy Technology 68(2), 281-290. https://doi.org/10.1111/1471-0307.12189

2. Bansal, S., Mangal, M., Sharma, S.K., Yadav, D.N., Gupta, R.K. (2016): Optimization of process conditions for developing yoghurt like probiotic product from peanut. LWT-Food Science and Technology 73, 6-12. https://doi.org/10.1016/j.lwt.2016.04.059
3. Davaatseren, M., Hur, H.J., Yang, H.J., Hwang, J.T., Park, J.H., Kim, H.J., Kim, MJ., Kwon, DY., Sung, M.J. (2013): Taraxacum official (dandelion) leaf extract alleviates high-fat diet-induced nonalcoholic fatty liver. Food and chemical toxicology 58, 30-36. https://doi.org/10.1016/j.fct.2013.04.023

4. Dias, M.I., Barros, L., Alves, R.C., Oliveira, M. B.P., Santos-Buelga, C., Ferreira, I.C. (2014): Nutritional composition, antioxidant activity and phenolic compounds of wild Taraxacum sect. Ruderalia. Food Research International 56, 266-271. https://doi.org/10.1016/j.foodres.2014.01.003

5. Escudero. N.L., Arellano, M.L.D., Fernández, S., Albarracín, G., Mucciarelli, S. (2003): Taraxacum officinale as a food source. Plant Foods for Human Nutrition 58(3), 1-10. https://doi.org/10.1023/B:QUAL.0000040365.90180. b3

6. Everett, D.W., McLeod, R.E. (2005): Interactions of polysaccharide stabilisers with casein aggregates in stirred skim-milk yoghurt. International Dairy Journal 15(11), 1175-1183. https://doi.org/10.1016/j.idairyj.2004.12.004

7. Ghaima, K.K., Hashim, N.M., Ali, S.A. (2013): Antibacterial and antioxidant activities of ethyl acetate extract of nettle (Urtica dioica) and dandelion (Taraxacum officinale). Journal of Applied Pharmaceutical Science 3(5), 96.

8. Glibowski, P., Rybak, P. (2016): Rheological and sensory properties of stirred yoghurt with inulin-type fructans. International Journal of Dairy Technology 69(1), 122-128. https://doi.org/10.1111/1471-0307.12231

9. Hashemi, S.M.B., Amininezhad, R., Shirzadinezhad, E., Farahani, M., Yousefabad, S. H.A. (2016): The antimicrobial and antioxidant effects of Citrus aurantium L. Flowers (Bahar Narang) extract in traditional yoghurt stew during refrigerated storage. Journal of Food Safety 36, 153-161. https://doi.org/10.1111/jfs.12222

10. Hekmat, S., Reid, G. (2006): Sensory properties of probiotic yoghurt is comparable to standard yogurt. Nutrition Research 26(4), 163-166. https://doi.org/10.1016/j.nutres.2006.04.004

11. Hu, C., Kitts, D.D. (2003): Antioxidant, prooxidant, and cytotoxic activities of solvent-fractionated dandelion (Taraxacum officinale) flower extracts in vitro. Journal of agricultural and food chemistry 51(1), 301-310. https://doi.org/10.1021/jf0258858

12. Hussein, M.M., Hassan, F.A.M., Daym, H.H.A., Salama, A., Enab, A.K., El-Galil, A.A.A. (2011): Utilization of some plant polysaccharides for improving yoghurt consistency. Annals of Agricultural Sciences 56(2), 97-103. https://doi.org/10.1016/j.aoas.2011.05.010

13. Keogh, M.K., O'Kennedy, B.T. (1998): Rheology of stirred yogurt as affected by added milk fat, protein and hydrocolloids. Journal of Food Science 63, 108-112. https://doi.org/10.1111/j.1365-2621.1998.tb15687.x 
14. Kiros, E., Seifu, E., Bultosa, G., Solomon, W.K. (2016): Effect of carrot juice and stabilizer on the physicochemical and microbiological properties of yoghurt. LWT-Food Science and Technology 69, 191-196. https://doi.org/10.1016/j.lwt.2016.01.026

15. Li, J., Guo, M. (2006): Effects of polymerized whey proteins on consistency and water-holding properties of goats milk yogurt. Journal of Food Science 71(1), C34-C38. https://doi.org/10.1111/j.1365-2621.2006.tb12385.x

16. Liu, D., Tang, H., Zhao, Y., Cui, F., Lu, J. (2016): Characterization of the adsorption behavior of aqueous cadmium on nanozero-valent iron based on orthogonal experiment and surface complexation modeling. Chinese Journal of Chemical Engineering 24(9), 1270-1274. https://doi.org/10.1016/j.cjche.2016.05.042

17. Menke, K., Stephan,H., Felenda, J., Stintzing, F., Beckmann, C., Schramm, A., Zuzak, T.J. (2015): Dandelion (Taraxacum officinale) extracts supply antitumour effects of mistletoe in pediatric cancer cells. Phytomedicine 22, S25-S26. https://doi.org/10.1016/j.phymed.2015.05.067

18. Miocinovic, J., Miloradovic, Z., Josipovic, M., Nedeljkovic, A., Radovanovic, M., Pudja, P. (2016): Rheological and textural properties of goat and cow milk set type yoghurts. International Dairy Journal 58, 43-45. https://doi.org/10.1016/j.idairyj.2015.11.006

19. Oliveira, A., Alexandre, E.M.C., Coelho, M., Lopes, C., Almeida, D.P.F., Pintado, M. (2015): Incorporation of strawberries preparation in yoghurt: Impact on phytochemicals and milk proteins. Food Chemistry 171, 370-378. https://doi.org/10.1016/j.foodchem.2014.08.107

20. Parsa, P., Alizadeh, M., Rezazad Bari, M., Akbarian Moghar, A. (2015): Dispensation of probiotic yoghurt production enriched with phytosterols. International Journal of Dairy Technology 68(4), 557-564. https://doi.org/10.1111/1471-0307.12207

21. Settachaimongkon, S., Nout, M.R., Fernandes, E.C.A., Hettinga, K.A., Vervoort, J.M., van Hooijdonk, T.C., Zwietering, M.H., Smid, E.J., van Valenberg, H.J. (2014): Influence of different proteolytic strains of Streptococcus thermophilus in co-culture with Lactobacillus delbrueckii subsp. bulgaricus on the metabolite profile of set-yoghurt. International Journal of Food Microbiology 177, 29-36. https://doi.org/10.1016/j.ijfoodmicro.2014.02.008

22. Settachaimongkon, S., v. Valenberg, H.J.F., Gazi, I., Nout, M.J.R., v. Hooijdonk, T.C.M., Zwietering, M.H., Smid, E.J. (2016): Influence of Lactobacillus plantarum WCFS1 on post-acidification, metabolite formation and survival of starter bacteria in set-yoghurt. Food Microbiology 59, 14-22. https://doi.org/10.1016/j.fm.2016.04.008
23. Slocum, S., Jasinski, E.M., Anantheswaran, R.C., Kilara, A. (1988): Effect of sucrose on protelysis in yogurt during incubation and storage. Joutnal of Dairy Science 71(3), 589-595. https://doi.org/10.3168/jds.S0022-0302(88)79595-8

24. Staffolo, M.D., Bertola, N., Martino, M. (2004): Influence of dietary fiber addition on sensory and rheological properties of yogurt. International Dairy Journal 14(3), 263-268. https://doi.org/10.1016/j.idairyj.2003.08.004

25. Sørensen, K.I., Curic-Bawden, M., Junge, M.P., Janzen, T., Johansen, E. (2016): Enhancing the sweetness of yoghurt through metabolic remodeling of carbohydrate metabolism in Streptococcus thermophilus and Lactobacillus delbrueckii subsp. bulgaricus. Applied and Environmental Microbiology 82(12), 3683-3692. https://doi.org/10.1128/AEM.00462-16

26. Tang, J., Gong, G., Su, H., Wu, F., Herman, C. (2016): Performance evaluation of a novel method of frost prevention and retardation for air source heat pumps using the orthogonal experiment design method. Applied Energy 169, 696-708. https://doi.org/10.1016/j.apenergy.2016.02.042

27. Wang, H.B. (2014): Cellulase-assisted extraction and antibacterial activity of polysaccharides from the dandelion Taraxacum officinale. Carbohydr Polym 103, 140-142. https://doi.org/10.1016/j.carbpol.2013.12.029

28. Williams, C.A., Goldstone, F., Greenham, J. (1996): Flavonoids, cinnamic acids and coumarins from the different tissues and medicinal preparations of $\mathrm{Ta}$ raxacum officinale. Phytochemistry 42(1), 121-127. https://doi.org/10.1016/0031-9422(95)00865-9

29. Wu, T., Yan, J., Liu, R., Marcone, M.F., Aisa, H.A., Tsao, R. (2012): Optimization of microwave-assisted extraction of phenolics from potato and its downstream waste using orthogonal array design. Food Chemistry 133(4), 1292-1298. https://doi.org/10.1016/j.foodchem.2011.08.002

30. Wu, X., Leung, D.Y. (2011): Optimization of biodiesel production from camelina oil using orthogonal experiment. Applied Energy 88(11), 3615-3624. https://doi.org/10.1016/j.apenergy.2011.04.041

31. You, Y., Yoo, S., Yoon, H.G., Park, J., Lee, Y.H., Kim, S., Oh, K.T., Lee, J., Cho, H.Y., Jun, W. (2010): In vitro and in vivo hepatoprotective effects of the aqueous extract from Taraxacum officinale (dandelion) root against alcohol-induced oxidative stress. Food and Chemical Toxicology 48(6), 1632-1637. https://doi.org/10.1016/j.fct.2010.03.037 